\title{
Perspectiva interamericana sobre la afectación de la libertad de menores en procedimientos migratorios
}

Fecha de recepción: 28 de enero de 2015

Fecha de aceptación: 14 de septiembre de 2015

Doi: dx.doi.org/10.12804/acdi9.1.2016.06

\section{Fernando Arlettaz}

Resumen: En su reciente opinión consultiva sobre los derechos y garantias de niñas y niños en el contexto de la migración y/ o en necesidad de protección internacional, la Corte Interamericana de Derechos Humanos ha expuesto el estado del derecho interamericano en relación con los menores migrantes. Uno de los temas de esa opinión, abordado en este artículo, es el relativo a la posibilidad y las condiciones de la afectación de libertad de menores en relación con procedimientos migratorios. Aunque las soluciones dadas por la Corte testimonian la fuerza expansiva de los derechos humanos, habría sido deseable una mayor precisión técnica en el pronunciamiento.

Palabras clave: afectación de libertad de menores, menores migrantes, sistema interamericano de derechos humanos.

* Universidad de Zaragoza - Unisangil. Este artículo se ha desarrollado en el marco del proyecto "Derecho de asilo en la jurisprudencia interamericana" (Grupo de Estudios Constitucionales, Unisangil). fernandoarlettaz@yahoo.com.ar

Para citar este artículo: Arlettaz, Fernando, "Perspectiva interamericana sobre la afectación de la libertad de menores en procedimientos migratorios", Anuario Colombiano de Derecho Internacional (ACDI), 2016, 9, pp. 197-231. Doi: dx.doi.org/10.12804/acdi9.1.2016.06 


\section{An inter-American Prespective on the Rights of Minors in Migration Proceedings}

Abstract: In its recent consultative opinion on the "Rights and Guarantees of Boys and Girls Within The Context of Migrations and/ or the Need for International Protection", the Inter-American Court of Human Rights has expounded upon the state of Inter- American law as regards the migration of minors. One of the themes of the opinion, and taken up in this article, relates to the possibility and conditions under which the liberty of minors is affected in relation to migration proceedings. Even though the solutions given by the Court are a testimony to the strong expansion of human rights, more technical precision would have been desirable in the decision.

Keywords: affectation to the liberty of minors, minor migrants, Inter- American system of Human Rights.

Perspectiva interamericana sobre a afetação da liberdade de menores em procedimentos migratórios

Resumo: Em sua recente Opinião Consultiva sobre os Direitos e garantias de crianças no contexto da migração e/ou em necessidade de proteção internacional, a Corte Interamericana de Direitos Humanos tem exposto o estado do direito interamericano em relação com os menores migrantes. Um dos temas dessa Opinião, abordado neste artigo, é o relativo à possibilidade e as condições da afetação de liberdade de menores em relação com procedimentos migratórios. Ainda que as soluções dadas pela Corte testemunham a força expansiva dos direitos humanos, haveria sido desejável uma maior precisão técnica no pronunciamento.

Palavras-chave: afetação de liberdade de menores, menores migrantes, sistema interamericano de direitos humanos.

\section{Introducción}

En agosto de 2014, la Corte Interamericana de Derechos Humanos emitió su Opinión Consultiva OC-21/14 sobre los derechos y garantías de niñas 
y niños en el contexto de la migración y/o en necesidad de protección internacional. ${ }^{1}$ En ella, la Corte dio respuesta a las preguntas planteadas por Argentina, Brasil, Paraguay y Uruguay (que actuaron conjuntamente como miembros del Mercosur) sobre el estatuto jurídico de los menores de edad migrantes. Los solicitantes señalaban que, aunque existe en el continente una tendencia a la adecuación de las legislaciones migratorias a los estándares internacionales, todavía persiste una grave situación de afectación de derechos humanos de los menores de edad migrantes. La solicitud indicaba que las mayores migraciones se daban desde América Latina y el Caribe hacia América del Norte y Europa, y estimaba que buena parte de estos migrantes eran menores de edad.

La solicitud también llamaba la atención sobre las políticas restrictivas que en materia migratoria aplican los países desarrollados. ${ }^{2}$

La respuesta de la Corte, según ella misma indicó, se inserta en un proceso de desarrollo progresivo del derecho internacional de los derechos humanos. Algunas de las consideraciones formuladas por la Corte ya habían sido insinuadas en un caso contencioso anterior: el caso Familia Pacheco Tineo vs. Bolivia. ${ }^{3}$ De hecho, desde hace algunos años se viene advirtiendo un incremento en el número de casos relativos a migración tratados por la jurisprudencia interamericana. ${ }^{4}$ Aunque por supuesto se trata de una opinión consultiva que, como tal, no se refiere a una situación concreta, a nadie escapa su importancia en relación con la particular situación de crisis producida por la llegada de menores migrantes a la frontera sur de los Estados Unidos. ${ }^{5}$

1 Corte Interamericana de Derechos Humanos (Corte IDH), Derechos y garantías de niñasy niños en el contexto de la migración y/o en necesidad de protección internacional, Opinión Consultiva OC-21/2013 del 19 de agosto de 2014, Serie A No 21.

2 Solicitud de opinión consultiva sobre niñez migrante ante la Corte Interamericana de Derechos $\mathrm{Hu}$ manos presentada por Argentina, Brasil, Paraguay y Uruguay, Buenos Aires, 6 de abril de 2011, en www.observatoriomercosur.org.uy

3 Corte IDH, Familia Pacheco Tineo vs. Bolivia, sentencia del 25 de noviembre de 2013 (excepciones preliminares, fondo, reparaciones y costas), Serie C No 272.

4 Olea, Helena, "Los derechos humanos de las personas migrantes: respuestas del sistema interamericano", en El sistema interamericano de protección de los derechos humanos y los derechos de las poblaciones migrantes, las mujeres, los pueblos indigenas y los niños, niñas y adolescentes, Instituto Interamericano de Derechos Humanos, San José, 2004, p. 12.

5 Ver "Child migration crisis in the United States", colección de documentos del Migration Policy Institute, en http://www.migrationpolicy.org/programs/us-immigration-policyprogram/child-migration-crisis-united-states. En relación con las reacciones jurídicas en 
Algunas cuestiones conceptuales deben ser esclarecidas de modo preliminar. En el vocabulario de la Corte, los términos niño y niña designan a toda persona que no haya cumplido 18 años de edad, salvo que hubiese alcanzado antes la mayoría de edad por mandato de ley (la Corte sigue criterios generales del derecho internacional, en particular la Convención sobre Derechos del Niño, dado que los instrumentos interamericanos no contienen normas al respecto). ${ }^{6} \mathrm{La}$ Corte es insistente en la utilización de la expresión niño o niña. Para aligerar la lectura de este trabajo, utilizaremos en algunos casos expresiones genéricas (como menor de edad o infancia), en el entendimiento de que incluyen a las personas de los dos sexos.

Por otra parte, la Corte habla de menores de edad migrantes para hacer referencia a quienes, con mayor precisión, deberían ser calificados como menores de edad extranjeros: los menores de edad que se encuentran en, o pretenden ingresar a, el territorio de un Estado que no es el de su nacionalidad. Los conceptos de extranjero y migrante, aunque estrechamente vinculados, no son sinónimos. Extranjeros, según es generalmente aceptado, son aquellas personas que se encuentran en el territorio de un Estado que no es el de su nacionalidad, ya sea porque poseen la nacionalidad de otro Estado (extranjeros en sentido estricto), ya sea porque no poseen ninguna nacionalidad (apátridas). En cambio, el concepto de migrante se utiliza para designar a la persona que migra, es decir, a la que cambia su lugar de residencia originario (normalmente, el del país donde ha nacido) por uno nuevo. ${ }^{7}$ Hay extranjeros que no son migrantes (por ejemplo: personas que han nacido en el territorio de un Estado de cuya nacionalidad, por el juego

los Estados Unidos, ver la nota de prensa "Judge orders release of inmigrant children detained by the us", The New York. Times, 25 de julio de 2015, en http://www.nytimes. com/2015/07/26/us/detained-immigrant-children-judge-dolly-gee-ruling.html?_r=1

6 Corte IDH, Condición jurídica y derechos humanos del niño, Opinión Consultiva OC-17/02 del 28 de agosto de 2002, Serie A No 17, párr. 42; Corte IDH, Derechos y garantías de niñas... op. cit., párr. 49.

7 Aunque tal uso no es unánime en derecho internacional, es el que hace la Corte en la opinión consultiva sobre migrantes indocumentados. Allí dice que migrante es un "término genérico que abarca tanto al emigrante como al inmigrante", siendo el inmigrante la "persona que llega a otro Estado con el propósito de residir en él" y el emigrante la "persona que deja un Estado con el propósito de trasladarse a otro y establecerse en él”. Corte IDH, Condición jurídica y derechos de los migrantes indocumentados, Opinión Consultiva OC-18/03 del 17 de septiembre de 2003, Serie A N 18 , párr. 69. En la opinión consultiva que comentamos, reproduce literalmente las anteriores definiciones. Corte IDH, Derechos y garantías de niñas..., op. cit., párr. 49. Sobre la distinción conceptual señalada, ver Arlettaz, Fernando, 
de las reglas aplicables, carecen); y hay migrantes que no son extranjeros (por ejemplo: personas que migran a un país en el que nunca antes habían estado, pero cuya nacionalidad tienen porque la han recibido de sus padres por ius sanguinis). En la opinión consultiva que comentamos, la Corte hace un uso bastante promiscuo de estos términos. Esta imprecisión conceptual ya había sido señalada en relación con pronunciamientos anteriores. ${ }^{8}$ Sin embargo, para seguir la terminología que usa la Corte, hablaremos en este trabajo de menores de edad migrantes en el sentido de menores de edad extranjeros.

La Corte realiza además una distinción entre niñas o niños no acompañados y niñas o niños separados. Los primeros son aquellos que están separados de ambos progenitores y de otros parientes y no están al cuidado de un adulto al que, por ley o costumbre, incumbe esa responsabilidad. ${ }^{9}$ En cambio, los segundos son aquellos que están separados de ambos progenitores o de sus tutores legales o habituales, pero no necesariamente de otros parientes adultos. ${ }^{10}$

Las preguntas de los Estados que solicitaron la opinión que aquí comentamos apuntaban a tres grandes núcleos temáticos. El primer núcleo temático tenía que ver con la situación de los menores de edad migrantes en general. El segundo se refería a la eventual afectación de la libertad de esos menores de edad. El tercer núcleo temático era el de las medidas de protección internacional que pueden ser requeridas por esos menores de edad. En este trabajo, abordaremos el segundo núcleo. Dividiremos nuestro estudio en tres partes. Primero, analizaremos los principios generales del sistema interamericano sobre la afectación de la libertad de las personas en el contexto de procesos migratorios. Aclaramos que hacemos uso de la expresión proceso migratorio en un sentido amplio que incluye cualquier proceso o procedimiento en el que se han de determinar los derechos y deberes de una persona bajo la legislación migratoria, ya tenga naturaleza

Extranjeros e inmigrantes: cuatro cuestiones de derecho internacional y filosofía jurídica, Fundación Aequitas, Madrid, 2014.

$8 \quad$ Ver Arlettaz, Fernando, "Extranjeros, migrantes y trabajadores migrantes en la jurisprudencia interamericana”, Revista de Derecho Migratorio y Extranjería, 2013, 36, pp. 247-260.

9 Corte IDH, Derechos y garantías de niñas..., op. cit., párr. 49 (con mención del Comité de los Derechos del Niño [CDN], Observación General $N^{o}$ 6: Trato de los menores no acompañados y separados de su familia fuera de su país de origen, UN Doc. CRC/GC/2005/6, 1 de septiembre de 2005, párr. 7).

10 Corte IDH, Derechos y garantías de niñas..., op. cit., párr. 49 (con mención del CDN, Observación General $N^{0} 6 \ldots$ op. cit., párr. 8). 
judicial, administrativa o cualquier otra. En la segunda parte, abordaremos los principios generales que rigen la situación de los menores de edad migrantes en el sistema interamericano. Finalmente, en la tercera parte haremos confluir las dos temáticas previamente abordadas y nos referiremos a la privación de libertad de menores de edad en el contexto de procesos migratorios según la reciente opinión consultiva.

Antes de entrar en las tres secciones apuntadas, sin embargo, resulta necesario hacer una mención al valor jurídico de la opinión que comentamos. Y esto no solo en relación con los Estados partes en la Convención Americana, sino también y particularmente en los Estados miembros de la Organización de Estados Americanos (OEA) que no son parte de la Convención. Como dijimos más arriba, los principales destinatarios de la migración en América son los Estados Unidos y Canadá, ninguno de los cuales es parte de la Convención Americana.

Los Estados que son miembros de la OEA pero no forman parte en la Convención obviamente no están obligados por las disposiciones de esta última, aunque sí están bajo el imperio de la Declaración Americana. A pesar de que la Declaración no es un tratado, la Corte Interamericana ha afirmado que no carece de efectos jurídicos, ya que los derechos en ella enunciados han de entenderse integrados en las obligaciones de la Carta de la OEA. ${ }^{11}$ La Comisión Interamericana, bajo cuya supervisión están todos los Estados miembros de la OEA (sean o no parte en la Convención), también ha dicho que la Carta torna obligatoria la Declaración. ${ }^{12}$

Por otra parte, si está claro que las sentencias dictadas por la Corte en casos contenciosos tienen un carácter vinculante, no sucede lo mismo con sus opiniones consultivas. La Corte ha dicho que una opinión consultiva "no tiene el carácter vinculante de una sentencia en un caso contencioso, [pero] tiene, en cambio, efectos jurídicos innegables". ${ }^{13}$ La Corte, sin embargo, no ha sido muy clara respecto de qué significa tener efectos jurídicos

11 Corte IDH, Interpretación de la Declaración Americana de los Derechos y Deberes del Hombre en el marco del artículo 64 de la Convención Americana sobre Derechos Humanos, Opinión Consultiva OC-10/89 del 14 de julio de 1989, Serie A No 10.

12 Comisión Interamericana de Derechos Humanos (Comisión IDH), James Terry Roach y Jay Pinkerton (Estados Unidos), Informe No 3/87 (admisibilidad y fondo) del 27 de marzo de 1987, caso 9647.

13 Corte IDH, Informes de la Comisión Interamericana de Derechos Humanos (art. 51 Convención Americana sobre Derechos Humanos), Opinión Consultiva OC-15/97 del 14 de noviembre de 1997, Serie A No 15, párr. 26. 
innegables. Ante esta situación, un punto de vista doctrinal señala que las opiniones consultivas carecen de carácter obligatorio. ${ }^{14}$ Otra perspectiva doctrinal considera en cambio, y a pesar de lo que dice la propia Corte, que las respuestas dadas al amparo del inciso 1 del artículo $64^{15}$ tienen carácter vinculante para todos los Estados partes en la Convención; y que las dadas al amparo del inciso 2 del artículo $64^{16}$ son vinculantes para el Estado parte en la Convención que las solicita. ${ }^{17}$

Desde nuestra perspectiva, cualquiera que sea el efecto que se atribuya a las opiniones consultivas, este solo resultaría predicable en relación con aquellos Estados que han suscrito la Convención Americana; o que sin haberla suscrito participan en el proceso del que resulta la opinión consultiva, ya sea porque solicitan la opinión, ${ }^{18}$ ya sea porque presentan observaciones. ${ }^{19}$ Lo que parece inapropiado es extender el efecto de una opinión consultiva a aquellos Estados miembros de la OEA que ni son parte en la Convención Americana ni han participado en su adopción. Esta última afirmación es válida incluso cuando la Corte interpreta la Declaración Americana, ya que, aunque la Declaración en sí misma extiende sus

14 Buergenthal, Thomas, "The Inter-American Court of Human Rights", The American Journal of International Law, 1982, 76, (2), pp. 244 y ss.

15 Consulta de los Estados miembros de la OEA o de los órganos enumerados en el capítulo $\mathrm{X}$ de la Carta de la OEA, en lo que les competa, sobre la interpretación de la Convención Americana o de otros tratados concernientes a la protección de los derechos humanos en los Estados americanos.

16 Opinión sobre la compatibilidad de las leyes internas de un Estado miembro de la OEA y cualquiera de los instrumentos internacionales mencionados en el inciso 1.

17 Faúndez Ledesma, Héctor, El sistema interamericano de protección de los derechos humanos: aspectos institucionales y procesales, Editorial IIDH, San José de Costa Rica, 2004, pp. 992-993. En el mismo sentido, Salvioli, Fabián, "La competencia consultiva de la Corte Interamericana de Derechos Humanos: marco legal y desarrollo jurisprudencial", en Homenaje y reconocimiento a Antônio Cançado Trindade, Editorial Sergio Fabris, Brasilia, 2004, tomo III, pp. 466-469. Según esta perspectiva, si un Estado no parte en la Convención solicita una opinión de la Corte, tal opinión será vinculante para ese Estado cuando entre a ser parte en la Convención.

18 Según el artículo 64 de la Convención Americana, cualquier Estado miembro de la OEA puede solicitar una opinión consultiva, aunque no sea parte en la Convención.

19 Según el artículo 67 del Reglamento de la Corte, las solicitudes de opiniones consultivas se notifican a todos los Estados miembros de la OEA, que pueden presentar observaciones escritas. 
efectos a todos los Estados miembros de la OEA, esta extensión no puede predicarse de las interpretaciones que la Corte haga de esa Declaración.

A pesar de que las conclusiones del párrafo anterior se siguen fácilmente del efecto relativo de los tratados, tanto la Corte como la Comisión sostienen el parecer contrario. En la opinión consultiva sobre migrantes indocumentados, la Corte dijo que las conclusiones allí obtenidas se aplican "a los Estados miembros de la OEA que han firmado indistintamente la Carta de la OEA, suscrito la Declaración Americana, la Declaración Universal, o han ratificado el Pacto Internacional de Derechos Civiles y Políticos, independientemente de que hayan o no ratificado la Convención Americana o alguno de sus protocolos facultativos" (cursiva nuestra) ${ }^{20}$ La Comisión siguió el mismo criterio en su informe sobre las migraciones en los Estados Unidos, ${ }^{21}$ además de sostener que la Declaración debe interpretarse a la luz de la Convención incluso respecto de los Estados que no son parte en esta última. ${ }^{22}$

No vemos de qué manera pueden imponerse a un Estado las conclusiones de un órgano convencional cuando ese Estado ni es parte en el tratado que ha dado origen a este órgano ni ha participado en el procedimiento por el cual se adoptan esas conclusiones. Recuérdese que, según el artículo 35 de la Convención de Viena sobre el derecho de los tratados celebrados entre Estados, para que un tratado dé origen a una obligación para un tercer Estado, es necesario que tal Estado acepte expresamente y por escrito esa obligación. Dado que ningún Estado miembro de la OEA que no sea parte en la Convención Americana intervino en el procedimiento que dio origen a la opinión consultiva que aquí comentamos, no parece haber manera de que los efectos de esta se extiendan más allá del ámbito de los Estados parte en la Convención. ${ }^{23}$

20 Corte IDH, Condición juridica y derechos de los migrantes indocumentados, op. cit., párr. 60.

21 Comisión IDH, Informe sobre migraciones en los Estados Unidos: detenciones y debido proceso, 30 de diciembre de 2010, OEA/Ser.L/V/II. Doc.78/10, párr. 32.

22 Comisión IDH, Juan Raúl Garza (Estados Unidos), Informe No 52/01 (fondo) del 4 de abril de 2001, caso 12243, párrs. 88-89; Comisión IDH, Informe sobre la situación de los derechos bumanos de los solicitantes de asilo en el marco del sistema canadiense de determinación de la condición de refugiado, 28 de febrero de 2000, OEA/Ser.L/V/II.106 Doc. 40 rev., párr. 38.

23 El único efecto de una opinión consultiva que podría extenderse a los Estados no parte en la Convención que no han participado en el procedimiento de su adopción es su genérico carácter de precedente internacional integrante de la jurisprudencia como fuente auxiliar. Una tercera opinión doctrinal sobre el valor de las opiniones consultivas (diferente de las dos 


\section{Afectación de la libertad de los migrantes}

En este apartado, nos referiremos a la afectación de la libertad de los migrantes. Si bien en algunos de los pronunciamientos interamericanos se vislumbra una distinción entre privación de libertad (la forma más severa de afectación de la libertad) y simples restricciones a la libertad (formas menos importantes de afectación), la mayoría de los documentos que constituyen el acervo interamericano relativo a migrantes se refieren a la primera de esas figuras. Por ello, dejaremos la distinción entre privación y simples restricciones para el apartado relativo a la afectación de libertad de los menores migrantes (dado que en la opinión consultiva que nos interesa se establece esa distinción) y aquí abordaremos los criterios generales sobre la privación de libertad.

Según la definición de la Comisión, constituye privación de libertad

cualquier forma de detención, encarcelamiento, institucionalización, o custodia de una persona, por razones de asistencia humanitaria, tratamiento, tutela, protección, o por delitos e infracciones a la ley, ordenada por o bajo el control de facto de una autoridad judicial o administrativa o cualquier otra autoridad, ya sea en una institución pública o privada, en la cual no pueda disponer de su libertad ambulatoria. Se entiende entre esta categoría de personas, no solo a las personas privadas de libertad por delitos o por infracciones e incumplimientos a la ley, ya sean estas procesadas o condenadas, sino también a las personas que están bajo la custodia y la responsabilidad de ciertas instituciones, tales como: hospitales psiquiátricos y otros establecimientos para personas con discapacidades físicas, mentales o sensoriales; instituciones para niños, niñas y adultos mayores; centros para migrantes, refugiados, solicitantes de asilo o refugio, apátridas e indocumentados; y cualquier otra institución similar destinada a la privación de libertad de personas (la cursiva es nuestra). ${ }^{24}$

que citamos más arriba) reduce a esta consecuencia el efecto de las opiniones consultivas con carácter general (es decir, no solo respecto de los Estados no parte en la Convención Americana que no han participado en su adopción). Nikken, Pedro, "La función consultiva de la Corte Interamericana de Derechos Humanos", en Memoria del Seminario del Sistema Interamericano de Derechos Humanos en el Umbral del Siglo XXI, Corte Interamericana, San José, 2003, p. 176.

24 Comisión IDH, Principios y buenas prácticas sobre la protección de las personas privadas de libertad en las Américas, Resolución 1/08 del 13 de marzo de 2008, disposición general. 
Los migrantes son un grupo particularmente expuesto a sufrir diversas formas de privación de libertad. Por un lado, la legislación de muchos países configura como delito la infracción a las normas migratorias, castigándolo con privación de libertad. Por otro lado, existen diversas formas de privación de libertad de carácter administrativo que los Estados ponen en práctica en relación con procedimientos de carácter migratorio. ${ }^{25}$

Tanto la Convención Americana (artículo 7.1) ${ }^{26}$ como la Declaración Americana (artículo I) ${ }^{27}$ protegen la libertad ambulatoria. Estas protecciones, y sus especificaciones (incisos 2 a 7 del artículo 7 de la Convención y artículo XXV de la Declaración), son aplicables a los procesos migratorios.

La primera garantía para la protección de la libertad ambulatoria es la de la prohibición de las privaciones de libertad ilegales (artículo 7.2 de la Convención ${ }^{28}$ y xxv de la Declaración ${ }^{29}$ ) o arbitrarias (inciso 7.3 de la Convención). ${ }^{30}$ Aunque la Declaración no contiene una norma expresa relativa a la no arbitrariedad, la Comisión la ha juzgado implícita en el artículo XXV. ${ }^{31}$ Ambas disposiciones son de aplicación en los procedimientos relativos a la migración y la extranjería. ${ }^{32}$

Las exigencias de legalidad y de no arbitrariedad son diferentes y complementarias. ${ }^{33} \mathrm{La}$ exigencia de legalidad se refiere a la necesidad de

25 Rodríguez Pizarro, Gabriela, "Migrant workers. Report of the Special Rapporteur, Ms. Gabriela Rodríguez Pizarro, submitted pursuant to Commission on Human Rights resolution 2002/62", E/CN.4/2003/85, 30 de diciembre de 2002, párrs. 17-19.

26 Artículo 7.1: "Toda persona tiene derecho a la libertad y a la seguridad personales".

27 Artículo I: "Todo ser humano tiene derecho a la vida, a la libertad y a la seguridad de su persona".

28 Artículo 7.2: "Nadie puede ser privado de su libertad física, salvo por las causas y en las condiciones fijadas de antemano por las constituciones políticas de los Estados partes o por las leyes dictadas conforme a ellas".

29 Artículo XXV: "Nadie puede ser privado de su libertad sino en los casos y según las formas establecidas por leyes preexistentes $[\ldots]$ ".

30 Artículo 7.3: "Nadie puede ser sometido a detención o encarcelamiento arbitrarios".

31 Comisión IDH: Rafael Ferrer-Mazorra y otros (Estados Unidos), Informe No 51/01 (admisibilidad y fondo) del 4 de abril de 2001, caso 9903, párrs. 211-212.

32 Corte IDH, Nadege Dorzema y otros vs. República Dominicana, sentencia del 24 de octubre de 2012 (fondo, reparaciones y costas), Serie C No 251, párrs. 167-170; Comisión IDH, Derechos bumanos de los migrantes y otras personas en el contexto de la movilidad bumana en México, OEA/Ser.L/V/II. Doc.48/13, 30 de diciembre de 2013, párrs. 422-425.

33 En algunos casos sobre privación de libertad (no necesariamente relativos a migrantes) en los que la Corte declaró que la privación de libertad era ilegal, ella consideró innecesario 
que estén previamente establecidas en la ley las causas y condiciones de la privación de libertad. ${ }^{34}$ La no arbitrariedad exige que la privación de libertad: 1) persiga un fin legítimo, 2) sea razonable, 3) sea necesaria, 4) sea proporcionada, 5) no sea discriminatoria. ${ }^{35}$

Tratándose de extranjeros, el fin de la privación de libertad es el control de los flujos migratorios, que es una finalidad que legítimamente pueden perseguir los Estados. ${ }^{36} \mathrm{La}$ necesidad, por su parte, exige que no haya posibilidad de asegurar los fines de la política migratoria por un medio menos restrictivo. ${ }^{37}$

En síntesis, la privación de libertad de migrantes debe ser una medida excepcional. Los Estados deben establecer políticas migratorias que partan de la presunción de libertad. ${ }^{38} \mathrm{El}$ argumento de que la persona en cuestión representa una amenaza para la seguridad pública solo es aceptable en circunstancias excepcionales en las cuales existan serios indicios del riesgo que representa una persona. La sola existencia de antecedentes penales no es suficiente para sustentar la detención de un inmigrante una vez que ha cumplido la condena penal. ${ }^{39}$

analizar si además era arbitraria; sin embargo, no siempre ha seguido el mismo criterio. Corte IDH, Análisis de la jurisprudencia de la Corte Interamericana de Derechos Humanos en materia de integridad personal y privación de libertad (artículos 7 y 5 de la Convención Americana sobre Derechos Humanos), Corte IDH, San José, 2010, p. 11. Sobre privación de libertad en general (no limitada al supuesto de migrantes), pueden consultarse, entre otros, los casos clásicos Corte IDH, Velásquez Rodriguez vs. Honduras (fondo), sentencia del 29 de julio de 1988, Serie C $\mathrm{N}^{\circ}$ 4; Corte IDH, Gangaram Panday vs. Suriname (fondo, reparaciones y costas), sentencia del 21 de enero de 1994, Serie C No 16; Corte IDH, Chaparro Álvarezy Lapo Íñiguez vs. Ecuador (excepciones preliminares, fondo, reparaciones y costas), sentencia del 21 de noviembre de 2007, Serie C No 170 .

34 Comisión IDH, Derechos bumanos de los migrantes..., op. cit., párr. 442.

35 Comisión IDH: Rafael Ferrer-Mazorra y otros..., op. cit., párr. 242; Comisión IDH, Informe sobre inmigración en los Estados Unidos..., op. cit., párr. 39; Comisión IDH, Derechos bumanos de los migrantes..., op. cit., párr. 446.

36 Corte IDH, Vélez Loor vs. Panamá, sentencia del 23 de noviembre de 2010 (excepciones preliminares, fondo, reparaciones y costas), Serie C No 218, párr. 169.

37 Corte IDH, Vélez Loor vs. Panamá, ibíd., párr. 171; Corte IDH, Familia Pacheco Tineo, op. cit., párr. 131.

38 Comisión IDH: Rafael Ferrer-Mąorra y otros..., op. cit., párr. 219; Comisión IDH, Informe sobre inmigración en los Estados Unidos..., op. cit., párrs. 38-39.

39 Comisión IDH: Rafael Ferrer-Mazorra y otros..., op. cit., párr. 221; Comisión IDH, Informe sobre inmigración en los Estados Unidos..., op. cit., párr. 39. 
La normativa de extranjería suele venir acompañada de un régimen sancionador que tiene por finalidad castigar las violaciones de las disposiciones relativas a la entrada, salida, estancia y actividades de los extranjeros en el territorio. Dicho régimen sancionador puede tener carácter penal o administrativo. Tales sanciones son en principio legítimas. ${ }^{40}$ Sin embargo, según el criterio de la Corte y de la Comisión, la privación de libertad de carácter punitivo (ya sea decidida en sede penal o administrativa) con base en una infracción migratoria constituye una privación de libertad arbitraria.

Según la Corte, la privación de libertad no es idónea ni necesaria cuando tiene un carácter punitivo, ya que implica sobrepasar el interés legítimo del Estado. ${ }^{41}$ A pesar de lo encomiable de esta afirmación, es necesaria una mayor precisión conceptual. En el caso Vélez Loor, en el que se llega a tal conclusión, la Corte es ambigua cuando dice que "la finalidad de imponer una medida punitiva al migrante que reingresara de manera irregular al país tras una orden de deportación previa no constituye una finalidad legítima" ${ }^{2}$ confundiendo el fin (el control de los flujos migratorios) con los medios (la imposición de una medida privativa de libertad de carácter punitivo).

En síntesis, según la Corte, la privación de libertad punitiva (de carácter penal o administrativo) estaría prohibida, pero otras formas de sanción (penal o administrativa) serían posibles. La Comisión va más lejos y afirma que las infracciones migratorias no deben tener un carácter penal. ${ }^{43}$ Esto implica ampliar la perspectiva de la Corte, para la cual el recurso al

40 Arlettaz, Fernando, "Límites convencionales a las políticas migratorias en el Sistema Interamericano de Derechos Humanos", Papeles ElTiempo de los Derechos, 2014, 17, en http:/ / www.tiempodelosderechos.es/docs/wp-17-14.pdf, consulta del 16 de enero de 2015.

41 Corte IDH, Vélez Loor vs. Panamá, op. cit., párrs. 169-170; Corte IDH, Familia Pacheco Tineo vs. Bolivia, op. cit., párr. 131.

42 Corte IDH, Vélez Loor vs. Panamá, op. cit., párr. 169.

43 Comisión IDH, Informe sobre inmigración en los Estados Unidos..., op. cit., párr. 38; Comisión IDH, Derechos humanos de los migrantes y otras personas en el contexto de la movilidad bumana en México, op. cit., párr. 417 (con mención del Consejo de Derechos Humanos, Informe del Relator Especial sobre los Derechos Humanos de los Migrantes, François Crépeau, 2 de abril de 2012, párr. 13). La Comisión afirma que la privación de libertad por razones migratorias tiene carácter civil (Comisión IDH, Informe sobre inmigración en los Estados Unidos..., op. cit., párr. 34). Si esto fuera así, se incurriría en una contradicción, ya que la privación de libertad con motivo del incumplimiento de obligaciones civiles está prohibida por la Declaración (artículo XXv), mientras que la Comisión, aunque relega la privación de libertad al rango de la excepcionalidad, no la prohíbe totalmente. No se trata de una privación de libertad de carácter civil, sino administrativo. 
sistema penal como forma de represión de las infracciones migratorias no estaría totalmente descartado, siempre que no se recurriera a la privación de libertad (se podría imponer, por ejemplo, una sanción penal de multa). ${ }^{44}$ Más aún: la Comisión es muy ambigua al afirmar que "el hecho de que un migrante se encuentre en situación irregular en un país no representa una lesión a un bien jurídico fundamental que requiera ser protegido a través del poder punitivo del Estado", justo después de reconocer que las sanciones que se derivan de infracciones administrativas son también una expresión del poder punitivo del Estado. ${ }^{45}$ Si tomáramos en serio esta afirmación de la Comisión, el Estado no podría sancionar ni penal ni administrativamente las infracciones al régimen migratorio, lo que no es una interpretación coherente del sistema en su conjunto.

En síntesis, partiendo de los precedentes de la Corte y de una interpretación razonable de los precedentes de la Comisión, se puede decir que las privaciones de libertad no punitivas aplicadas con la finalidad de satisfacer los objetivos de un proceso migratorio, que sean necesarias, proporcionadas, razonables y no discriminatorias, serán legítimas. Así, por ejemplo, la Corte ha aceptado que resulta legítimo, en los ingresos de frontera, retener a las personas para realizar controles de identificación. ${ }^{46}$ Para evitar la arbitrariedad, la decisión que ordena la privación de libertad debe establecer el fundamento jurídico razonado y objetivo sobre la procedencia y necesidad de dicha medida. ${ }^{47} \mathrm{El}$ mero listado de todas las normas que podrían ser aplicables no satisface el requisito de motivación suficiente. ${ }^{48}$

Por otra parte, en estos casos resulta también de aplicación el derecho a ser informado de las razones de la privación de libertad ${ }^{49}$ (artículo 7.4 de la Convención), ${ }^{50}$ que exige que se informe de las causas que

\footnotetext{
44 La perspectiva de la Corte, que la Comisión también abraza, tiene además otra consecuencia: la privación de libertad punitiva está siempre descartada, aunque sea aplicada por una vía no estrictamente penal (por ejemplo, un arresto administrativo).

45 Comisión IDH, Derechos humanos de los migrantes..., op. cit., párr. 427.

46 Corte IDH, Nadege Dorzema y otros vs. República Dominicana, op. cit., párr. 124.

47 Corte IDH, Vélez Loor vs. Panamá, op. cit., párr. 116.

48 Corte IDH, Vélez Loor vs. Panamá, ibíd., párr. 116.

49 Corte IDH, Nadege Doržema y otros vs. República Dominicana, op. cit., párr. 168.

50 Artículo 7.4: "Toda persona detenida o retenida debe ser informada de las razones de su detención y notificada, sin demora, del cargo o cargos formulados contra ella".
} 
motivan la privación de libertad en el caso concreto. ${ }^{51} \mathrm{La}$ información debe hacerse desde el momento mismo en que se lleva a cabo la privación de libertad. ${ }^{52}$ Por supuesto, se trata del derecho a ser informado de las verdaderas razones de la privación de libertad. Así, por ejemplo, resulta ilegítimo argumentar que la privación de libertad está relacionada con un control migratorio cuando en realidad se trata de un procedimiento de lucha contra el narcotráfico. ${ }^{53}$

La legitimidad de la privación de libertad debe ser controlada por una autoridad competente. La Convención se refiere a este derecho en dos preceptos: el artículo 7.5 establece el derecho a ser llevado ante una autoridad competente para ejercer funciones judiciales (no necesariamente un juez) y a ser juzgado en un plazo razonable o ser puesto en libertad; ${ }^{54}$ el artículo 7.6 establece el derecho a recurrir la privación de libertad ante un juez. ${ }^{55} \mathrm{El}$ artículo xxv de la Declaración fusiona ambos preceptos en uno solo, estableciendo el derecho a ser llevado ante un juez para que verifique la legalidad de la medida y a ser juzgado en un plazo razonable o ser puesto en libertad. ${ }^{56}$

A pesar de la diferencia de redacción, no parece que la interpretación que surge de estos preceptos deba ser divergente. Así, la persona

51 O'Donnell, Daniel, Derecho internacional de los derechos humanos, Superior Tribunal de Justicia del Distrito Federal, 2012, p. 338.

52 Comisión IDH, Derechos bumanos de los migrantes..., op. cit., párr. 448.

53 Corte IDH, Tibi vs. Ecuador, sentencia del 7 de septiembre de 2004 (excepciones preliminares, fondo, reparaciones y costas), Serie C No 114, párrs. 111-122.

54 Artículo 7.5: "Toda persona detenida o retenida debe ser llevada, sin demora, ante un juez u otro funcionario autorizado por la ley para ejercer funciones judiciales y tendrá derecho a ser juzgada dentro de un plazo razonable o a ser puesta en libertad, sin perjuicio de que continúe el proceso. Su libertad podrá estar condicionada a garantías que aseguren su comparecencia en el juicio".

55 Artículo 7.6: “Toda persona privada de libertad tiene derecho a recurrir ante un juez o tribunal competente, a fin de que éste decida, sin demora, sobre la legalidad de su arresto o detención y ordene su libertad si el arresto o la detención fueran ilegales. En los Estados partes cuyas leyes prevén que toda persona que se viera amenazada de ser privada de su libertad tiene derecho a recurrir a un juez o tribunal competente a fin de que éste decida sobre la legalidad de tal amenaza, dicho recurso no puede ser restringido ni abolido. Los recursos podrán interponerse por sí o por otra persona".

56 Artículo XXv: "[...] Todo individuo que haya sido privado de su libertad tiene derecho a que el juez verifique sin demora la legalidad de la medida y a ser juzgado sin dilación injustificada, o, de lo contrario, a ser puesto en libertad [...]". 
privada de libertad por motivos migratorios debe ser llevada, sin demora, ante una autoridad (judicial o administrativa) que pueda resolver su caso o ser puesta en libertad. ${ }^{57}$ Es necesario que la persona comparezca personalmente y rinda declaración ante la autoridad competente, siendo insuficiente el simple conocimiento por parte de esta de que una persona está detenida. ${ }^{58}$ Por otro lado, debe existir siempre la posibilidad de pedir la revisión de la privación de libertad ante una autoridad judicial. ${ }^{59}$ Además, y en cualquier caso, la privación de libertad preventiva no puede durar más que un plazo razonable, ${ }^{60}$ el cual la persona debe ser puesta en libertad sin perjuicio de que continúe el proceso. La puesta en libertad referida debe hacerse antes de la expulsión. ${ }^{61}$ En el caso Nardege Dorzema, un grupo de inmigrantes haitianos fue privado de la libertad por militares dominicanos, sin que esta retención fuera en sí misma contraria al derecho dominicano. Sin embargo, la Corte juzgó que había existido una violación de la Convención, teniendo en cuenta que los migrantes fueron expulsados por los militares dominicanos, y la garantía del artículo 7.5, según la cual, las personas deben ser llevadas ante la autoridad competente para ser juzgadas, no se había cumplido. ${ }^{62}$

57 Corte IDH, Tibi vs. Ecuador, op. cit., párr. 118; Corte IDH, Vélez Loor vs. Panamá, op. cit., párr. 107; Corte IDH, Nadege Dorzema y otros vs. República Dominicana, op. cit., párr. 172; Comisión IDH, Derechos humanos de los migrantes..., op. cit., párr. 453.

58 Corte IDH, Análisis de la jurisprudencia..., op. cit., pp. 53-54.

59 Corte IDH, Vélez Loor vs. Panamá, op. cit., párrs. 126-127; Corte IDH, Nadege Dorzema y otros vs. República Dominicana, op. cit., párr. 179; Comisión IDH, Loren Laroye Riebe Star, Jorge Barón Guttlein y Rodolfo Izal Elorz. (México), Informe No 49/99 (fondo) del 13 de abril de 1999, caso 11.610, párr. 40; Comisión IDH, Derechos humanos de los migrantes..., op. cit., párr. 455.

60 Corte IDH, Vélez Loor vs. Panamá, op. cit., párr. 117; Comisión IDH, Derechos humanos de los migrantes..., op. cit., párrs. 444 y 453 . No está muy claro si la Comisión deriva esta regla del artículo 7.5 o del artículo 7.3 de la Convención.

61 Sobre la expulsión de extranjeros en el Sistema Interamericano, ver Arlettaz, Fernando, "Extranjeros: expulsión y rechazo en frontera", Al Derecho y al Revés, 2013, 10. El relator especial de las Naciones Unidas sobre expulsión de extranjeros ha presentado sucesivos informes sobre diversos aspectos del tema. Para una visión de conjunto, ver Kamto, Maurice, "Informe preliminar sobre la expulsión de los extranjeros presentado por el señor Maurice Kamto, relator especial”, A/CN.4/554, 4 de abril de 2005.

62 Corte IDH, Nadege Dorzema y otros vs. República Dominicana, op. cit., párr. 139. 
Por otra parte, en el proceso migratorio han de aplicarse los principios del debido proceso (artículo 8 de la Convención ${ }^{63}$ y XXVI de la Declaración). ${ }^{64}$ El Estado no puede adoptar decisiones administrativas o judiciales sin respetar esas garantías mínimas. ${ }^{65} \mathrm{El}$ proceso legal debe ser garantizado a toda persona, independientemente de su estatus migratorio. ${ }^{66}$

63 Artículo 8: "1. Toda persona tiene derecho a ser oída, con las debidas garantías y dentro de un plazo razonable, por un juez o tribunal competente, independiente e imparcial, establecido con anterioridad por la ley, en la sustanciación de cualquier acusación penal formulada contra ella, o para la determinación de sus derechos y obligaciones de orden civil, laboral, fiscal o de cualquier otro carácter. 2. Toda persona inculpada de delito tiene derecho a que se presuma su inocencia mientras no se establezca legalmente su culpabilidad. Durante el proceso, toda persona tiene derecho, en plena igualdad, a las siguientes garantías mínimas: a) derecho del inculpado de ser asistido gratuitamente por el traductor o intérprete, si no comprende o no habla el idioma del juzgado o tribunal; b) comunicación previa y detallada al inculpado de la acusación formulada; c) concesión al inculpado del tiempo y de los medios adecuados para la preparación de su defensa; d) derecho del inculpado de defenderse personalmente o de ser asistido por un defensor de su elección y de comunicarse libre y privadamente con su defensor; e) derecho irrenunciable de ser asistido por un defensor proporcionado por el Estado, remunerado o no según la legislación interna, si el inculpado no se defendiere por sí mismo ni nombrare defensor dentro del plazo establecido por la ley; f) derecho de la defensa de interrogar a los testigos presentes en el tribunal y de obtener la comparecencia, como testigos o peritos, de otras personas que puedan arrojar luz sobre los hechos; g) derecho a no ser obligado a declarar contra sí mismo ni a declararse culpable, y h) derecho de recurrir del fallo ante juez o tribunal superior. 3. La confesión del inculpado solamente es válida si es hecha sin coacción de ninguna naturaleza. 4. El inculpado absuelto por una sentencia firme no podrá ser sometido a nuevo juicio por los mismos hechos. 5 . El proceso penal debe ser público, salvo en lo que sea necesario para preservar los intereses de la justicia".

64 Artículo XxvI: "Se presume que todo acusado es inocente, hasta que se pruebe que es culpable. Toda persona acusada de delito tiene derecho a ser oída en forma imparcial y pública, a ser juzgada por tribunales anteriormente establecidos de acuerdo con leyes preexistentes y a que no se le imponga penas crueles, infamantes o inusitadas".

65 Corte IDH, Vélez Loor vs. Panamá, op. cit., párr. 142; Corte IDH, Derechos y garantías de niñas..., op. cit., párr. 112; Corte IDH, Familia Pacheco Tineo vs. Bolivia, op. cit., párr. 132; Comisión IDH, Rafael Ferrer-Mazorra y otros..., op. cit., párr. 213; Comisión IDH, Andrea Mortlock (Estados Unidos), Informe No 63/08 (admisibilidad y fondo) del 25 de julio de 2008, caso 12.534, párr. 83; Comisión IDH, Informe sobre inmigración en los Estados Unidos..., op. cit., 30 de diciembre de 2010, párr. 40.

${ }^{66}$ Corte IDH, Condición jurídica y derechos de los migrantes indocumentados, op. cit., párrs. 121122; Corte IDH, Vélez Loor vs. Panamá, op. cit., párr. 143; Corte IDH, Derechos y garantías de niñas..., op. cit., párr. 113; Comisión IDH, Segundo informe de progreso del relator especial sobre los trabajadores migrantes, informe anual 2000, 16 de abril de 2001, párr. 90; Comisión IDH, Loren 
De particular relevancia, en relación con el debido proceso en casos migratorios, es la posibilidad de obtener asistencia consular. ${ }^{67}$

Los migrantes deben ser detenidos en establecimientos específicamente destinados a tal fin, que sean acordes a su situación legal y no en prisiones comunes, cuya finalidad es incompatible con la naturaleza de la detención de una persona por su situación migratoria. ${ }^{68}$ Esta distinción se debe a las diferentes finalidades de la privación de libertad.

En el caso de las personas privadas de libertad exclusivamente por cuestiones migratorias, los lugares de detención tienen que encontrarse diseñados de modo de garantizar condiciones materiales y un régimen adecuado para su situación legal, evitando en lo posible, la desintegración de los núcleos familiares. ${ }^{69}$ En consecuencia, el Estado debe adoptar las medidas positivas que sean necesarias para garantizar no solo el goce y ejercicio de aquellos derechos, cuya restricción no resulta un efecto colateral

Laroye Riebe Star..., op. cit., párr. 46; Comisión IDH, Wayne Smith (Estados Unidos), Informe $\mathrm{N}^{\circ}$ 56/06 (admisibilidad) del 20 de julio de 2006, caso 12.562, párr. 51.

67 La Corte ha dedicado al tema una opinión consultiva específica: Corte IDH, El derecho a la información sobre la asistencia consular en el marco de las garantias del debido proceso legal, Opinión Consultiva OC-16/99 del $1^{\circ}$ de octubre de 1999, Serie A No 16. Ver al respecto, Cançado Trindade, Antônio Augusto, "The humanization of consular law: the impact of Advisory Opinion $\mathrm{N}^{\circ} 16$ (1999) of the Inter-American Court of Human Rights on international case-law and practice", Chinese Journal of International Law, 2007, 6, (1), pp. 1-16. Aunque la Corte ha asociado mayoritariamente el derecho a la información consular con el debido proceso (artículo $8^{\circ}$ ), en algunos casos lo ha puesto bajo la órbita del derecho a ser informado de las causas de la detención (artículo 7.4). Corte IDH, Análisis de la jurisprudencia ..., op. cit., p. 48.

La Comisión ha determinado que podía considerar el grado hasta el cual el Estado parte ha hecho efectivos los requisitos del artículo 36 de la Convención de Viena sobre Relaciones Consulares para fines de evaluar el cumplimiento por parte de dicho Estado de los derechos de debido proceso. Comisión IDH, César Fierro (Estados Unidos), Informe No 99/03 (admisibilidad y fondo) del 29 de diciembre de 2003, caso 11.331, párr. 37; Comisión IDH, Roberto Moreno Ramos (Estados Unidos), Informe No 1/05 del 28 de enero de 2005, caso 12.430, párr. 72; Comisión IDH, Javier Suárez Medina (Estados Unidos), Informe $\mathrm{N}^{\circ}$ 91/05 del 24 de octubre de 2005, caso 12.421, párrs. 82-87; Comisión IDH, Medellín, Ramírez Cárdenas y Garcia Leal (Estados Unidos), Informe No 90/09 del 7 de agosto de 2009, caso 12.644, párrs. 97 y 125 (los casos de la Comisión eran relativos a extranjeros aunque los procesos involucrados no eran de materia migratoria).

68 Corte IDH, Vélę Loor vs. Panamá, op. cit., párr. 208; Comisión IDH, Principios y buenas prácticas..., op. cit., principio XIX; Comisión IDH, Informe sobre inmigración en los Estados Unidos..., op. cit., párrs. 76-77.

69 Corte IDH, Vélez Loor vs. Panamá, ibíd., párr. 209. 
necesario de la situación de privación de la libertad, sino también para asegurar que esta no genere un mayor riesgo de afectación a los derechos, a la integridad y al bienestar personal y familiar de las personas migrantes. ${ }^{70}$

\section{Menores de edad migrantes}

Según la jurisprudencia de la Corte ${ }^{71}$ los niños y niñas son titulares de los derechos humanos que corresponden a todos los seres humanos y gozan, además, de derechos especiales, a los que corresponden deberes específicos de la familia, la sociedad y el Estado, derivados de los artículos 19 de la Convención ${ }^{72}$ y VII de la Declaración. ${ }^{73}$ Los dos artículos, que se refieren en forma amplia a la protección de la infancia, ${ }^{74}$ irradian sus efectos en la interpretación de los demás derechos, en la medida en que se refieran a menores de edad. ${ }^{75} \mathrm{La}$ debida protección de sus derechos debe tomar en consideración sus características propias y la necesidad de propiciar su desarrollo, ofreciéndoles las condiciones necesarias para que desarrollen sus aptitudes con pleno aprovechamiento de sus potencialidades. ${ }^{76}$ Por otra parte, estas obligaciones deben interpretarse a la luz del corpus iuris de derecho internacional sobre los derechos de los menores de edad, en el cual tiene una posición fundamental la Convención sobre los Derechos del Niño. ${ }^{77}$

70 Ibíd.

71 Corte IDH, Condición jurídica y derechos humanos del niño, op. cit., párr. 54; Corte IDH, Atala Riffo y niñas vs. Chile, sentencia del 24 de febrero de 2012 (fondo, reparaciones y costas), Serie C No 239, párrs. 196-197; Corte IDH, Fornerón e bija vs. Argentina, sentencia del 27 de abril de 2012 (fondo, reparaciones y costas), Serie C No 242, párr. 45; Corte IDH, Furlany familiares vs. Argentina, sentencia del 31 de agosto de 2012 (excepciones preliminares, fondo, reparaciones y costas), Serie C No 246, párr. 125; Corte IDH, Mendoza y otros vs. Argentina, sentencia del 14 de mayo de 2013 (excepciones preliminares, fondo y reparaciones), Serie C No 260, párr. 140.

72 Artículo 19: "Todo niño tiene derecho a las medidas de protección que su condición de menor requieren por parte de su familia, de la sociedad y del Estado".

73 Artículo VII: "Toda mujer en estado de gravidez o en época de lactancia, así como todo niño, tienen derecho a protección, cuidados y ayuda especiales".

74 O’Donnell, Derecho internacional de los derechos humanos, op. cit., p. 830.

75 Corte IDH, Derechos y garantías de niñas..., op. cit., párr. 66.

76 Corte IDH, Condición jurídica y derechos humanos del niño, op. cit., párr. 56; Corte IDH, Familia Pacheco Tineo vs. Bolivia, op. cit., párr. 218; Corte IDH, Derechos y garantías de niñas..., op. cit., párr. 66.

77 Corte IDH, "Niños de la Calle" (Villagrán Morales y otros) vs. Guatemala, sentencia del 19 
El principio general que informa toda la opinión consultiva sobre los menores de edad migrantes es que los Estados deben priorizar el enfoque de los derechos humanos desde una perspectiva que tenga en cuenta en forma transversal los derechos de los niños y niñas, de modo que su protección y desarrollo integral deben primar por sobre cualquier consideración de nacionalidad o estatus migratorio. ${ }^{78}$ La idea de que un estatuto legal de protección debe primar sobre otro régimen que pueda entrar en conflicto con él aparece reiteradamente en la jurisprudencia de la Corte en relación con la migración. Así, por ejemplo, en la opinión consultiva sobre los derechos de los trabajadores indocumentados, la Corte dijo que el estatuto de trabajador debe prevalecer sobre la situación de migrante en condición irregular, y que por ello no se pueden restringir derechos de los trabajadores con base en la irregularidad migratoria. ${ }^{79}$

La tendencia a hacer prevalecer las reglas protectoras (las que protegen al trabajador, las que protegen a la infancia) sobre las reglas más restrictivas (las relativas a los migrantes) es digna de elogio desde el punto de vista ético, y testimonia la fuerza expansiva de los derechos humanos. Sin embargo, como veremos más abajo con detalle, en algunas ocasiones esta actitud de la Corte la lleva a declaraciones genéricas con buenas intenciones, que cuidan poco la coherencia técnica de las soluciones que brinda.

Para conseguir la protección debida a la infancia, cuatro principios emergentes de la Convención sobre los Derechos del Niño deben considerarse: 1) no discriminación; 2) interés superior del niño o niña; 3) respeto al derecho a la vida, la supervivencia y el desarrollo; 4) respeto a

de noviembre de 1999 (fondo), Serie C No 63, párrs. 192-194; Corte IDH, Condición jurídica y derechos bumanos del niño, op. cit., párr. 24; Corte IDH, Atala Riffo y niñas vs. Chile, op. cit., párrs. 108 y ss. y 196 y ss.; Corte IDH, Fornerón e bija vs. Argentina, op. cit., párr. 49; Corte IDH, Furlan y familiares vs. Argentina, op. cit., párrs. 126-127 y 228 y ss.; Corte IDH, Derechos y garantías de niñas..., op. cit., párr. 57. En los casos Atala Riffo, Fornerón, Furlan y Mendoza, así como en la opinión consultiva que aquí comentamos, la Corte desarrolla la idea de la autonomía progresiva, según la cual los niños y las niñas ejercen sus derechos de manera progresiva a medida que desarrollan un mayor nivel de autonomía personal. Corte IDH, Atala Riffo y niñas vs. Chile, op. cit., párr. 199; Corte IDH, Fornerón e bija vs. Argentina, op. cit., párr. 165; Corte IDH, Furlan y familiares vs. Argentina, op. cit., párr. 230; Corte IDH, Mendoza y otros vs. Argentina, op. cit., párr. 143; Corte IDH, Derechos y garantias de niñas..., op. cit., párr. 66.

78 Corte IDH, Derechos y garantías de niñas..., op. cit., párr. 68.

79 Corte IDH, Condición jurídica y derechos de los migrantes indocumentados, op. cit., párr. 133. 
la opinión del niño o niña en todo procedimiento que lo afecte, de modo que se garantice su participación. ${ }^{80}$

Por otra parte, la Corte señala también que la protección debida a la infancia puede necesitar ser complementada por medidas todavía más específicas, en consideración a la situación particular del menor de edad en cuestión (que puede pertenecer a un grupo étnico minoritario, ser una persona con discapacidad o vivir con el VIH/sida, así como ser víctima de trata, encontrarse separado o no acompañado, etc.). ${ }^{81}$ En este caso, se superponen dos o más estatutos protectores.

En aquellos procesos migratorios que involucren a menores de edad se deben otorgar las garantías del debido proceso, que pueden asumir ciertos componentes diferenciados. ${ }^{82}$ Así, algunas garantías son aplicables tanto respecto de los adultos como de los menores de edad: 1) el derecho a ser notificado de la existencia de un proceso migratorio y de la decisión que se adopte en él; 2) el derecho a ser oído y a participar en las diferentes etapas procesales; 3) el derecho a ser asistido gratuitamente por un traductor y/o intérprete; 4) el derecho a ser asistido por un representante legal y a comunicarse libremente con él; 5) el derecho al acceso efectivo a la comunicación y asistencia consular; 6) el derecho a recurrir la decisión ante un juez o tribunal superior con efectos suspensivos; 7) el derecho a una duración razonable del proceso. Otros derechos, en cambio, son específicos de los menores de edad: 1) el derecho a que los procesos migratorios sean llevados por un funcionario o juez especializado; 2) el derecho a que se designe un tutor en caso de niños o niñas no acompañados o separados; 3) el derecho a que la decisión que se adopte evalúe el interés superior del niño o niña y sea debidamente fundamentada.

De todas formas, incluso los derechos comunes a adultos y menores de edad pueden asumir ciertos rasgos específicos cuando son estos últimos los involucrados. Así, el derecho a la notificación (tanto de la iniciación del procedimiento como de la decisión que en él se adopte) requiere la existencia de personal capacitado para comunicarle al niño o niña que su

80 Corte IDH, Derechos y garantías de niñas..., op. cit., párr. 69. Ver también sobre la protección de la infancia, en el mismo sentido, Corte IDH, Fornerón e bija vs. Argentina, op. cit., párrs. 48 y ss.

81 Corte IDH, Derechos y garantías de niñas..., ibíd., párr. 71.

82 Corte IDH, Derechos y garantías de niñas..., ibíd., párr. 114. Ver también Corte IDH, Condición jurídica y derechos humanos del niño, op. cit., párr. 96. 
situación está siendo sometida a consideración administrativa o judicial. ${ }^{83}$ El derecho a ser oído debe ser interpretado a la luz del artículo 12 de la Convención sobre los Derechos del Niño (que se refiere a tal derecho), con la finalidad de que la participación del niño o niña se ajuste a su condición y no redunde en perjuicio de su interés. ${ }^{84}$ Los Estados deben garantizar que el proceso se desarrolle en un entorno que no sea intimidatorio, hostil, insensible o inadecuado a la edad del niño o niña y que el personal encargado de recibir el relato esté debidamente capacitado. ${ }^{85}$ En caso de que el niño o niña no hable el idioma en el que se desarrolla el proceso, debe ser asistido por un traductor o intérprete. Esta garantía tiene particular importancia en los casos de niños o niñas pertenecientes a comunidades indígenas. ${ }^{86}$

En cuanto a la representación legal, la jurisprudencia de la Corte no es tajante en relación a cuándo es necesaria. En casos anteriores (no relativos a procesos migratorios) ha precisado que "las circunstancias de un procedimiento particular, su significación, su carácter y su contexto en un sistema legal particular, son factores que fundamentan la determinación de si la representación legal es o no necesaria para el debido proceso". ${ }^{87}$ Sin embargo, parecería que esta asistencia es ineludible cuando hay menores de edad insertos en un proceso migratorio, ya que en la opinión que comentamos el tribunal ha dicho que "los Estados tienen la obligación de garantizar a toda niña o niño involucrado en un proceso migratorio la asistencia jurídica a través del ofrecimiento de servicios estatales gratuitos de representación legal". ${ }^{88}$ Por otra parte, el acceso a la comunicación y asistencia consular debe ser tratado de manera prioritaria por los Estados, en especial por las implicanciones que puede tener en el proceso de recabar información y documentación en el país de origen, así como para

83 Corte IDH, Derechos y garantías de niñas..., ibíd., párr. 117.

84 Ibíd., párr. 122. Ver también Corte IDH, Condición jurídica y derechos bumanos del niño, op. cit., párr. 102; Corte IDH, Atala Riffo y niñas vs. Chile, op. cit., párr. 196.

85 Corte IDH, Derechos y garantías de niñas..., ibíd., párr. 123.

86 Ibíd., párr. 125.

87 Corte IDH, Excepciones al agotamiento de los recursos internos (arts. 46.1, 46.2. a y 46.2.b, Convención Americana sobre Derechos Humanos), Opinión Consultiva 11/90 del 10 de agosto de 1990, Serie A No 11, párr. 28.

88 Corte IDH, Derechos y garantias de niñas..., op. cit., párr. 125. 
velar por que la repatriación voluntaria únicamente sea dispuesta si así lo recomienda el interés superior del niño o niña. ${ }^{89}$

La resolución que se dicte en el proceso migratorio deberá estar motivada, y explicar la forma en que se tuvieron en cuenta las opiniones expresadas por el niño o niña y en que se ha evaluado su interés superior. ${ }^{90}$ El derecho a recurrir la decisión debe permitir, entre otras cuestiones, identificar si la decisión ha tenido debidamente en consideración el principio del interés superior. ${ }^{91}$ La duración razonable del proceso implica que los procesos administrativos o judiciales que conciernen a la protección de derechos humanos de niños o niñas deben ser manejados con una celeridad excepcional por parte de las autoridades, aunque es necesario que se extiendan lo suficiente como para garantizar que el niño o niña sea adecuadamente oído. ${ }^{92}$

En cuanto a las garantías específicas, hay que tener en cuenta que las personas que intervienen en los procesos relativos a menores de edad migrantes deben estar debidamente capacitadas, de forma que puedan identificar las necesidades especiales de protección del niño o niña. ${ }^{93}$ En el caso de los menores de edad no acompañados o separados, además, resulta necesario el nombramiento de un tutor, que debe hacerse cargo tan pronto como sea posible y al tanto hasta que el niño o niña llegue a la mayoría de edad, abandone permanentemente la jurisdicción del Estado o desaparezca la causa por la cual fue nombrado. ${ }^{94}$ Los procesos administrativos o judiciales no pueden ser iniciados hasta tanto el tutor no haya sido nombrado. ${ }^{95}$ No pueden ejercer la función de tutor los organismos o individuos cuyos intereses puedan entrar en conflicto con los del niño o niña. En el caso de un niño o niña separado de su familia, "normalmente se nombrará tutor al familiar adulto que lo acompañe o quien le dispense cuidados sin ser familiar directo, salvo que haya indicios de que ese arreglo beneficie al menor, por ejemplo, cuando éste haya sido maltratado por el adulto acompañante". ${ }^{96}$

\footnotetext{
89 Ibíd.

90 Ibíd., párr. 139.

91 Ibíd., párr. 141.

92 Ibíd., párr. 143.

93 Ibíd., párr. 121.

94 Ibíd., párr. 133.

95 Ibíd., párr. 132.

96 Ibíd., párr. 135.
} 


\section{Afectación de libertad de menores migrantes}

A diferencia de otros pronunciamientos de la Corte Interamericana, en los que se había abordado la cuestión de la afectación de la libertad de las personas de modo global y bajo el rótulo de privación de libertad, en la opinión consultiva sobre niñez migrante la Corte distingue entre la privación de libertad y las afectaciones menores que caben en el rótulo de restricción menor de la libertad. ${ }^{97}$ La diferencia entre la privación de la libertad y la restricción de la libertad radica en el grado de intensidad de la medida. ${ }^{98}$

\subsection{Privación de libertad}

Para dar respuesta a las preguntas formuladas por los Estados, la Corte adopta un concepto de privación de libertad ${ }^{99}$ que es equivalente al concepto de detención utilizado por los solicitantes y que es sustancialmente semejante al concepto dado por la Comisión que nosotros hemos transcrito más arriba. Lo que caracteriza a tal privación "[...] es el hecho de que la persona, en este caso la niña y/o el niño, no pueden o no tienen la posibilidad de salir o abandonar por su propia voluntad el recinto o establecimiento en el cual se encuentra o ha sido alojado". ${ }^{100}$

El derecho internacional de los derechos humanos, en particular el que surge de la Convención de los Derechos del Niño, exige que la detención sea aplicada sobre menores solo como medida de último recurso y por el período de tiempo más corto posible. Sin embargo, en muchos países los menores son detenidos por largos períodos y en condiciones contrarias a los estándares internacionales. ${ }^{101}$

97 Ibíd., párr. 187 (con mención del Tribunal Europeo de Derechos Humanos [TEDH], Guzzardi vs. Italia, sentencia del 6 de noviembre de 1980, Aplicación № 7367/76, párrs. 92 y 93; TEDH, Nielsen vs. Dinamarca, sentencia del 28 de noviembre de 1988, Aplicación No 10929/84, párr. 67; TEDH, Medvedyev y otros vs. Francia [GS], sentencia del 29 de marzo de 2010, Aplicación No 3394/03, párr. 73).

98 Corte IDH, Derechos y garantías de niñas..., op. cit., párr. 182.

99 La Corte circunscribe su apreciación a los casos de niños en situación migratoria irregular o solicitantes de asilo que son sometidos a un procedimiento migratorio (que puede finalizar ordenando la expulsión al país de origen o bien permitiendo la estancia) en el cual podría darse una situación de privación de libertad. Corte IDH, Derechos y garantías de niñas..., ibíd., párr. 147.

100 Ibíd., párr. 145.

101 Rodríguez Pizarro, "Migrant workers...,” op. cit., párrs. 45-47. 
De acuerdo con los desarrollos interamericanos relativos a la justicia juvenil, la privación de libertad de menores de edad es una medida excepcional que debe ser aplicada, cuando proceda, por el menor tiempo posible. ${ }^{102}$ En el caso de los procedimientos migratorios, el estándar se hace todavía más exigente: no alcanza con confinar la privación de libertad al rango de ultima ratio; la privación de libertad debe ser totalmente proscrita. Así, en los procedimientos migratorios, la privación de libertad de adultos está proscrita si tiene carácter punitivo (según dijimos en el apartado 2); la privación de libertad de menores, por su parte, está proscrita siempre. ${ }^{103}$

En este punto, la Corte va más allá de lo que había dicho la Comisión un tiempo antes. Esta última había afirmado que el principio de excepcionalidad que rige la privación de libertad en general, y la privación de libertad por infracciones migratorias en particular, se hacía aún más estricto tratándose de menores de edad. Para la Comisión, solo circunstancias de mucho peso podrían justificar la privación de libertad de un menor de edad en el contexto de un proceso migratorio. Sin embargo, tal medida no estaba totalmente prohibida. ${ }^{104}$

Según la Corte, en cambio, la privación de libertad de menores de edad en el marco de un proceso migratorio excede siempre el requisito de necesidad, "toda vez que tal medida no resulta absolutamente indispensable a los fines de asegurar su comparecencia al proceso migratorio o para garantizar la aplicación de una orden de deportación”. ${ }^{105}$ La apreciación de la Corte resulta opinable. Es por supuesto acertado restringir la privación de libertad en el marco migratorio a situaciones de ultima ratio. Sin embargo, no parece que se pueda distinguir totalmente la situación de los menores de edad y la de los adultos sobre la base de la menor probabilidad de incomparecencia de los primeros al proceso migratorio. Si se quiere diferenciar ambas situaciones para tornar todavía más rigurosos los criterios de privación de libertad de los menores de edad en un proceso

\footnotetext{
102 Corte IDH, Instituto de Reeducación del Menor vs. Paraguay, sentencia del 2 de septiembre de 2004 (excepciones preliminares, fondo, reparaciones y costas), Serie C No 112, párrs. 230 y 231; Corte IDH, Mendoza y otros vs. Argentina, op. cit., párr. 162; Corte IDH, Derechos y garantías de niñas..., op. cit., párr. 149; Comisión IDH, Informe sobre justicia juvenil y derechos bumanos en las Américas, 13 de julio de 2011, OEA/Ser.L/V/II, párr. 248.

103 Corte IDH, Derechos y garantías de niñas..., ibíd., párr. 150.

104 Comisión IDH, Informe sobre inmigración en los Estados Unidos..., op. cit., párr. 51.

105 Corte IDH, Derechos y garantías de niñas..., op. cit., párr. 154.
} 
migratorio (o excluir totalmente esta posibilidad, como hace la Corte), habría que buscar otro argumento.

Además, según la Corte, la privación de libertad resultaría siempre desproporcionada, ya que no respondería al interés superior del menor de edad y podría ser reemplazada por medidas menos gravosas. ${ }^{106} \mathrm{El}$ punto de vista de la Corte evidencia cierta imprecisión conceptual. En efecto, para la Corte, lo que caracteriza la privación de libertad es que el menor de edad no puede salir o abandonar por su propia voluntad el recinto o establecimiento en el cual se encuentra o ha sido alojado. Ahora bien: cualquier procedimiento migratorio implica que las personas sean constreñidas a no abandonar el lugar en el que se encuentran, al menos durante cierto tiempo. Cualquier persona que llega a un aeropuerto, por ejemplo, no puede abandonar el espacio de tránsito hasta no pasar por el control migratorio correspondiente; en caso de que el personal encargado de la administración migratoria tenga dudas sobre la identidad de la persona o la autenticidad de su documentación, puede impedir que la persona abandone el lugar hasta tanto se hayan realizado las averiguaciones correspondientes, etc. Aunque este tipo de afectaciones a la libertad parecerían el paradigma de la mera restricción de libertad, la imprecisión de la definición dada por la Corte hace que ellas caigan dentro de la categoría de la privación de libertad (en contra, seguramente, del propio espíritu de la opinión consultiva).

Así que una de dos: o bien este tipo de medidas son efectivamente privaciones de libertad y por ello no pueden aplicarse a menores de edad (lo cual llevaría a la conclusión absurda de que los menores de edad no pueden someterse a controles migratorios, ya que todos conllevan cierta privación de libertad en el sentido enunciado; aunque la Corte no explicita esta conclusión, ella puede seguirse fácilmente de los propios términos de la opinión) ${ }^{107}$ o bien hay que revisar el concepto de privación de libertad dado por la Corte (que es coincidente con el de la Comisión, como ya vimos).

\footnotetext{
106 Ibíd.

107 Llevar las premisas de la Corte hasta sus últimas conclusiones resultaría contraproducente incluso para el interés del propio menor de edad. Porque el control migratorio en frontera (y la necesaria demora que este implica) busca también controlar que la movilidad internacional de los menores de edad sea conforme a las reglas sobre la autoridad parental o tutelar. En otras palabras: entre los fines del control de frontera también está evitar que los menores de edad se sustraigan o sean sustraídos indebidamente de la autoridad bajo la cual están puestos por la ley.
} 
Evidentemente, la segunda vía es la más adecuada. Una pista en este sentido nos da la ya mencionada distinción que realiza la propia Corte entre privación de libertad y restricción menor a la libertad. Una demora (como las que se producen en los aeropuertos antes de pasar el control migratorio) podría ser un ejemplo típico de restricción a la libertad que no es privación de libertad. Pero la Corte pierde la oportunidad de clarificar conceptualmente su punto de vista cuando, citando su jurisprudencia anterior, vuelve a confundir restricción y privación de libertad: "Bajo determinadas circunstancias una demora, así sea con meros fines de identificación de la persona, puede constituir una privación de la libertad física". ${ }^{108}$

En otro orden, la Corte especifica que, en caso de menores de edad acompañados, estos deben permanecer junto a sus progenitores; y si el procedimiento migratorio exige, en ausencia de menores de edad, la privación de libertad de los adultos, el imperativo de no privación de libertad que beneficia a los descendientes se extiende a los progenitores por razón de la unidad familiar. ${ }^{109}$ De este modo, no son los menores de edad quienes deben seguir la suerte de los adultos (ser privados de libertad), sino los adultos los que deben seguir la suerte de los menores de edad (permanecer en libertad por razón de la unidad familiar). La Corte es aquí más radical de lo que había sido antes la Comisión: mientras que la primera prohíbe totalmente la privación de libertad de los padres en estos casos, la segunda permitía en principio tal detención siempre que se considerase cómo podía afectar esta al interés del menor de edad. ${ }^{110}$

En el caso de menores de edad no acompañados o separados, el Estado se encuentra obligado a promover en forma prioritaria las medidas de protección especial orientadas en su interés superior. ${ }^{111}$ En principio habría resultado aquí aplicable la regla de separación en categorías enunciada por la Comisión, por la cual los menores de edad habrían debido estar privados de su libertad en un lugar diferente de los adultos. ${ }^{112}$ Sin embargo,

\footnotetext{
108 Corte IDH, Torres Millacura y otros vs. Argentina, sentencia del 26 de agosto de 2011 (fondo, reparaciones y costas), Serie C No 229, párr. 76; Corte IDH, Derechos y garantías de niñas..., op. cit., párr. 187.

109 Corte IDH, Derechos y garantías de niñas..., ibíd., párr. 158.

110 Comisión IDH, Informe sobre la situación de los derechos humanos..., op. cit., párr. 166; Comisión IDH, Informe sobre inmigración en los Estados Unidos..., op. cit., párr. 49.

111 Corte IDH, Derechos y garantias de niñas..., op. cit., párr. 157.

112 Comisión IDH, Principios y buenas prácticas..., op. cit., principio XIX.
} 
dado el rechazo frontal a la privación de libertad de menores de edad en procesos migratorios enunciado por la Corte, tal regla carece de sentido.

\subsection{Medidas alternativas a la privación de libertad}

Los Estados están obligados a implementar medidas alternativas a la privación de libertad, que deben ser definidas según las circunstancias particulares de cada caso, atendiendo al interés superior del menor de edad. ${ }^{113}$ Tales medidas pueden ser, por ejemplo, la notificación periódica a las autoridades o la permanencia en centros de alojamiento abiertos o en un lugar designado. ${ }^{114}$

En caso de aplicación de estas medidas alternativas, deben respetarse las siguientes garantías mínimas: 1) adopción por la autoridad administrativa o judicial competente; 2) tomar en cuenta las opiniones de los menores de edad sobre sus preferencias; 3 ) velar por que el interés superior del menor de edad sea una consideración primordial al tomar la decisión; y 4) garantizar el derecho a revisión de la decisión, en caso de considerarse que no es la medida adecuada, la menos lesiva o que se está utilizando de forma punitiva. ${ }^{115}$

Como señalamos antes, entre las medidas alternativas legítimas se encuentra el alojamiento de los menores de edad en instituciones especializadas. Tal medida solo es posible cuando "se comprueba una necesidad excepcional, ineludible o imperiosa de cautelar en forma preferente los fines del proceso migratorio y no hay otra opción menos lesiva". ${ }^{116}$ Tales centros pueden ser establecimientos estatales o privados, pero la delegación a la iniciativa privada conlleva la obligación de fiscalización por parte del Estado para garantizar una efectiva protección de los derechos de las personas bajo su jurisdicción y para que los servicios públicos sean provistos a la colectividad sin ningún tipo de discriminación y de la forma más efectiva posible. ${ }^{117}$

\footnotetext{
113 Corte IDH, Derechos y garantías de niñas..., op. cit., párr. 170. Ver en el mismo sentido, aunque refiriéndose a la privación de libertad de menores en conflicto con la ley penal, Comisión IDH, Justicia juvenily derechos humanos en las Américas, op. cit., párrs. 267-270.

114 Corte IDH, Derechos y garantías de niñas..., ibíd., párr. 162.

115 Ibíd., párr. 169.

116 Ibíd., párr. 173.

117 Ibíd., párr. 174.
} 
El régimen de tales centros debe garantizar el respeto de determinados principios: 1) carácter abierto; 2) separación respecto de personas acusadas o condenadas por delitos penales; 3 ) unidad familiar y separación de adultos y menores de edad; 4) condiciones materiales y atención adecuados a la protección del menor de edad.

El carácter abierto de los centros se deduce de la prohibición de aplicar medidas privativas de libertad a menores de edad en el contexto de procedimientos migratorios. ${ }^{118}$

La necesidad de separación de las personas migrantes de las personas acusadas o condenadas por delitos penales ya había sido señalada por la jurisprudencia anterior de la Corte, como señalamos arriba, y es reafirmada ahora. ${ }^{119}$

En cuanto a los menores de edad que se encuentran junto a sus familiares, de conformidad con los artículos 17 de la Convención y VI de la Declaración sobre la Protección de la Familia, la regla debe ser que permanezcan con sus padres o quienes hagan sus veces, evitando en lo posible la desintegración de núcleos familiares, salvo que su interés superior dicte lo contrario. ${ }^{120}$ En cambio, los menores de edad no acompañados o separados en ningún caso pueden ser alojados con adultos. ${ }^{121}$ Por otra parte, el espacio de alojamiento de los menores de edad no acompañados o separados debe estar dividido según las necesidades específicas de grupos etarios y diferenciado de los centros para familias. ${ }^{122}$

Finalmente, los centros deben garantizar el alojamiento, la manutención, el reconocimiento médico, el asesoramiento legal, el apoyo educativo y la atención integral a los menores de edad, y disponer de una serie de servicios de atención especializada en razón de las necesidades particulares de cada niño o niña. ${ }^{123}$

\subsection{Restricción menor de la libertad}

La pregunta número 6 planteada por los Estados solicitantes de la opinión consultiva apuntaba a saber cuáles son las garantías del debido proceso

\footnotetext{
118 Ibíd., párr. 180.

119 Ibíd., párr. 170.

120 Ibíd., párr. 177.

121 Ibíd.

122 Ibíd., párr. 179.

123 Ibíd., párr. 182.
} 
que resultan aplicables en casos de restricción de la libertad de los menores de edad en el contexto de un procedimiento migratorio. Sin embargo, al responder a la pregunta, la Corte señaló que se referiría a

una serie de garantías relevantes que se tornan operativas ante situaciones de restricción de libertad personal —entre otras, interferencias severas a la libertad ambulatoria, retenciones, aprehensiones, arrestos o detenciones breves - que pueden constituir o eventualmente derivar, por las circunstancias del caso en concreto, en una medida que materialmente se corresponda a una privación de libertad en el entendido que tales situaciones podrían ocurrir en la práctica.

La respuesta de la Corte parece doblemente inadecuada. En primer lugar, porque no está contestando estrictamente lo que se le ha preguntado. En efecto, se le ha preguntado por las garantías del debido proceso aplicables en casos de restricción de libertad y ella responde por las garantías del debido proceso aplicables en casos de privación de libertad, reconociendo expresamente que se trata de situaciones diferentes. ${ }^{124}$

En segundo lugar, y esto es más grave porque evidencia una confusión conceptual bastante grande, porque la Corte reconoce que las medidas de privación de libertad podrían ocurrir en la práctica a pesar de

124 Agradecemos a uno de los árbitros anónimos haber llamado nuestra atención sobre el hecho de que el sistema interamericano no es estrictamente un sistema de justicia rogada, por lo que afirmar que la Corte resuelve extra petita resultaría problemático. La Corte, en efecto, ha sostenido que puede mantener el conocimiento de un trámite de opinión consultiva incluso si el Estado solicitante retira la solicitud (Corte IDH, resolución del 14 de abril de 1997, Considerandos, párr. 4). Puede también reordenar las preguntas que le son presentadas, para clarificar su pronunciamiento (ver, por ejemplo, Corte IDH, Exigibilidad del derecho de rectificación o respuesta [arts. 14.1, 1.1 y 2, Convención Americana sobre Derechos Humanos], Opinión Consultiva OC7/86 del 29 de agosto de 1986, Serie A No 7, párr. 12). Sin embargo, no es menos cierto que la función consultiva no puede ejercerse de oficio, según surge del propio artículo 64 de la Convención. Además, según señala autorizada doctrina, aunque la competencia consultiva es amplia, no es ilimitada: la Corte no puede responder consultas que no le han sido formuladas. Salvioli, Fabián, "La competencia consultiva...", op. cit., p. 443. Teniendo en cuenta estas particularidades de la función contenciosa, nos limitamos a llamar la atención sobre el hecho de que la Corte no ha contestado estrictamente lo que se le estaba preguntando, sin pronunciarnos sobre si la respuesta dada cae dentro de la competencia de la Corte (por ejemplo, porque, aunque no responde estrictamente a la pregunta formulada, se refiere a un tema conexo) o si excede tal competencia. 
ser contrarias a los estándares de derechos humanos según ella misma lo ha establecido. Ahora bien, si tales privaciones de libertad ocurren en la práctica, estamos ante una violación de los estándares interamericanos que generará responsabilidad del Estado y no ante una situación lícita que deba ser rodeada de garantías. La Corte ha dicho que la privación de libertad de menores de edad en el contexto de procedimientos migratorios es, en sí misma ilícita: poco importa entonces que se respeten unas psendogarantías por ella enunciadas.

Supongamos entonces que, a pesar de los vaivenes conceptuales, cuando la Corte habla de garantías, se refiere a las garantías aplicables en caso de restricción menor de la libertad y no de privación de libertad. Al fin y al cabo, la propia Corte dice más adelante que en "lo que respecta a las garantías aplicables a las situaciones de restricción de la libertad, los artículos 7 de la Convención y XXV de la Declaración adquieren una centralidad manifiesta"125 (aunque luego, el enunciar las garantías concretas, vuelve a hablar de la legalidad de la privación de la libertad, del derecho a ser informado de los motivos de la privación de la libertad...).

Las garantías mencionadas por la Corte son sustancialmente idénticas a las que corresponden a la privación de libertad de adultos en el contexto de un proceso migratorio, tal como hemos enunciado más arriba. En primer lugar, cualquier restricción de la libertad debe respetar el principio de legalidad expresamente consagrado en los artículos 7.2 de la Convención y XXV de la Declaración. ${ }^{126}$ Igualmente, se debe respetar la prohibición de arbitrariedad de los artículos 7.3 de la Convención y XXV de la Declaración, que excluye causas y métodos que, aun siendo legales, sean irrazonables, imprevisibles o faltos de proporcionalidad. ${ }^{127}$

En segundo lugar, respecto del derecho a ser informado de los motivos de la restricción de la libertad, la Corte recuerda su jurisprudencia, según la cual, la información de los motivos y razones del arresto o de la detención debe darse cuando esta se produce. ${ }^{128}$ Los Estados deben

\footnotetext{
125 Igualmente, resulta relevante el artículo 37.d) de la Convención sobre los Derechos del Niño. Corte IDH, Derechos y garantías de niñas..., op. cit., párr. 188.

126 Ibíd., párr. 191 (con mención de la Corte IDH, Nadege Dorzema y otros vs. República Dominicana, op. cit., párr. 126).

127 Ibíd., párr. 192 (con mención de la Corte IDH, Gangaram Panday vs. Suriname, op. cit., párr. 47; Corte IDH, Nadege Dorzema y otros vs. República Dominicana, op. cit., párr. 133).

128 Ibíd., párr. 195 (con mención de la Corte IDH, Juan Humberto Sánchez vs. Honduras, sentencia del 7 de junio de 2003 [excepción preliminar, fondo, reparaciones y costas], Serie C
} 
garantizar la asistencia por un traductor o intérprete, en el caso de que el menor de edad no comprendiera el idioma del país receptor. ${ }^{129}$ Finalmente, es necesario que el menor de edad tenga a su disposición toda la información necesaria (sobre derechos, servicios y procedimientos) y que sea comunicada de acuerdo con su grado de madurez.

En tercer lugar, el derecho a ser llevado, sin demora, ante un juez u otro funcionario autorizado por la ley para ejercer funciones judiciales, y que debe tomar en cuenta la especial vulnerabilidad de los menores de edad. ${ }^{130}$ Para satisfacer la garantía establecida en el artículo 7.5 de la Convención, se debe asegurar que el funcionario autorizado por la ley cumpla con las características de imparcialidad e independencia ${ }^{131}$ y que esté facultado para poner en libertad a la persona. ${ }^{132}$

En cuarto lugar, existe el derecho a notificar a una tercera persona que se está bajo custodia del Estado; ${ }^{133}$ por ejemplo, a un familiar, tutor o representante legal. ${ }^{134}$ Según la Corte, la notificación sobre el derecho a establecer contacto con un familiar, tutor o representante legal, debe ser

No 99, párr. 82; Corte IDH, Chaparro Álvarezy Lapo Íñiguez vs. Ecuador, sentencia del 21 de noviembre de 2007 [excepciones preliminares, fondo, reparaciones y costas], Serie C N ${ }^{\circ}$ 172, párr. 70).

129 Ibíd., párr. 197.

130 Ibíd., párr. 198 (con mención de la Corte IDH, Vélez Loor vs. Panamá, op. cit., párr. 107; Corte IDH, Nadege Dorzema y otros vs. República Dominicana, op. cit., párr. 136). Ver en el mismo sentido, aunque refiriéndose a la privación de libertad de menores en conflicto con la ley penal, Comisión IDH, Justicia juvenily derechos bumanos en las Américas, op. cit., 253; Corte IDH, "Niños de la calle" (Villagrán Morales y otros) vs. Paraguay, op. cit., párr. 135.

131 Corte IDH, Derechos y garantías de niñas..., ibíd., párr. 198 (con mención de la Corte IDH, Vélez Loor vs. Panamá, op. cit., párr. 108; Corte IDH, Nadege Dorzema y otros vs. República Dominicana, op. cit., párr. 137).

132 Ibíd., párr. 198 (con mención de la Corte IDH, Vélez Loor vs. Panamá, op. cit., párr. 108; Corte IDH, Nadege Dorzema y otros vs. República Dominicana, op. cit., párr. 137).

133 Ibíd., párr. 199 (con mención de la Corte IDH, Bulacio vs. Argentina, sentencia del 18 de septiembre de 2003 [fondo, reparaciones y costas], Serie C No 100, párr. 130; Corte IDH, Tibi vs. Ecuador, op. cit., párr. 112). Ver en el mismo sentido, aunque refiriéndose a la privación de libertad de menores en conflicto con la ley penal, Comisión IDH, Justicia juvenil y derechos bumanos en las Américas, op. cit., 259.

134 Corte IDH, Derechos y garantías de niñas..., ibíd., párr. 199 (con mención de la Corte IDH, Tibi vs. Ecuador, op. cit., párr. 112). Ver en el mismo sentido, aunque refiriéndose a la privación de libertad de menores en conflicto con la ley penal, Comisión IDH, Justicia juvenil y derechos humanos en las Américas, op. cit., 259. 
hecha al momento de la retención o detención. ${ }^{135}$ Luego de realizar esta afirmación, la Corte incorpora una particularidad bastante enigmática, que ya había aparecido en casos anteriores relativos a menores: ${ }^{136}$ "Pero cuando se trata de menores de edad deben adoptarse, además, las providencias necesarias para que efectivamente se haga la notificación, teniendo en cuenta el interés superior de la niña o del niño". ${ }^{137}$ ¿Qué quiere decir esto? ¿Que cuando no se trata de menores no es necesario que se adopten medidas tendentes a que la notificación sea efectiva? Por otra parte, la Corte dice que, en los casos en que resulte procedente, el menor de edad debe tener la posibilidad de contactarse con organismos internacionales, como el Alto Comisionado de las Naciones Unidas para los Refugiados, el Comité Internacional de la Cruz Roja, el Fondo de las Naciones Unidas para la Infancia o la Organización Internacional para las Migraciones. ${ }^{138}$

En quinto lugar, el derecho a la información y acceso efectivo a la asistencia consular es reconocido a toda persona extranjera detenida fuera de su país de origen. ${ }^{139}$

En sexto lugar, los Estados deben nombrar a los menores un representante legal que le brinde asistencia jurídica ${ }^{140} \mathrm{y}$, en el caso de menores de edad no acompañados o separados de sus familias, un tutor. ${ }^{141}$

Finalmente, es de aplicación la garantía del babeas corpus que permite recurrir ante un juez o tribunal competente, a fin de que este decida, sin demora, sobre la legalidad de la afectación de la libertad. ${ }^{142}$ En el caso de menores de edad migrantes, este procedimiento debe ostentar un carácter prioritario. $^{143}$

\footnotetext{
135 Corte IDH, Derechos y garantías de niñas..., ibíd., párr. 200 (con mención de la Corte IDH, El derecho a la información..., op. cit., párr. 106).

136 Corte IDH, Análisis de la jurisprudencia..., op. cit., p. 46, mencionando los casos Bulacio y Gómez Paquiyauri. Corte IDH, Bulacio vs. Argentina..., op. cit., párr. 130; Corte IDH, Hermanos Gómez Paquiyauri vs. Perú (fondo, reparaciones y costas), sentencia del 8 de julio de 2004, Serie C No 110, párr. 93.

137 Corte IDH, Derechos y garantías de niñas..., op. cit., párr. 200 (con mención de la Corte IDH, Bulacio vs. Argentina, op. cit., párr. 130).

138 Ibíd., párr. 201.

139 Ibíd., párr. 202.

140 Ibíd., párr. 204.

141 Ibíd., párr. 205.

142 Ibíd., párr. 206.

143 Ibíd.
} 


\section{Conclusiones}

La opinión consultiva sobre niñez migrante, dictada por la Corte Interamericana en el año 2014, ha tratado temas de gran trascendencia en relación con la situación de los menores de edad migrantes. Este artículo ha abordado uno de esos temas: el de la legitimidad de la privación de libertad de estos menores.

La Corte Interamericana ha ejercido, a través de la opinión estudiada, su labor consultiva, desgajando la interpretación que según su entender ha de darse a los preceptos de la Convención Americana y de la Declaración Americana. La opinión tiene aspectos positivos: ella está bien documentada y aporta precisiones de interés en la materia. Además, la Corte no se contenta con una interpretación literal de los preceptos involucrados, sino que avanza en una interpretación progresiva que testimonia la fuerza expansiva de los derechos humanos.

Sin embargo, en no pocos pasajes la coherencia técnica de las soluciones adoptadas no es evidente. Parece como si en su afán de expandir los derechos reconocidos la Corte descuidara la consistencia técnica de sus propuestas para hacer bienintencionadas afirmaciones genéricas. Por otra parte, y además de estos problemas técnicos, la lectura de la opinión se torna bastante pesada por un estilo denso y repetitivo que poco contribuye a la concisión esperable en una decisión judicial.

La opinión consultiva es un paso positivo hacia la consolidación de los derechos humanos en América. Pero ha de estar en guardia contra el hecho de que largas enumeraciones de derechos pueden hacer pensar que la cuestión de fondo está resuelta, que se ha conseguido ya un mundo real más justo. Esto, por supuesto, está muy lejos de la realidad. A veces resulta preferible una enumeración de derechos acotada y bien resguardada que largos textos jurídicos con declamaciones que luego chocan frontalmente con la realidad.

\section{Referencias}

Arlettaz, Fernando, "Extranjeros, migrantes y trabajadores migrantes en la jurisprudencia interamericana", Revista de Derecho Migratorio y Extranjería, 2013, 36, pp. 247-260.

Arlettaz, Fernando, "Extranjeros: expulsión y rechazo en frontera", $A l$ Derecho y al Revés, 2013, 10. 
Arlettaz, Fernando, "Límites convencionales a las políticas migratorias en el Sistema Interamericano de Derechos Humanos", Papeles El Tiempo de los Derechos, 2014, 17, en http:/ /www.tiempodelosderechos.es/ docs/wp-17-14.pdf, consulta del 16 de enero de 2015.

Arlettaz, Fernando, Extranjeros e inmigrantes: cuatro cuestiones de derecho internacional y filosofía jurídica, Fundación Aequitas, Madrid, 2014.

Buergenthal, Thomas, "The Inter-American Court of Human Rights", The American Journal of International Law, 1982, 76, (2), pp. 244 y ss.

Cançado Trindade, Antônio Augusto, "The humanization of consular law: the impact of Advisory Opinion No 16 (1999) of the InterAmerican Court of Human Rights on international case-law and practice", Chinese Journal of International Law, 2007, 6, (1), pp. 1-16.

Corte IDH, Análisis de la jurisprudencia de la Corte Interamericana de Derechos Humanos en materia de integridad personal y privación de libertad (articulos 7 y 5 de la Convención Americana sobre Derechos Humanos), Corte IDH, San José, 2010.

Faúndez Ledesma, Héctor, El sistema interamericano de protección de los derechos humanos: aspectos institucionales y procesales, Editorial IIDH, San José de Costa Rica, 2004.

Kamto, Maurice, "Informe preliminar sobre la expulsión de los extranjeros presentado por el señor Maurice Kamto, relator especial”, A/ CN.4/554, 4 de abril de 2005.

Nikken, Pedro, "La función consultiva de la Corte Interamericana de Derechos Humanos", en Memoria del Seminario del Sistema Interamericano de Derechos Humanos en el Umbral del Siglo XXI, Corte Interamericana, San José, 2003.

O’Donnell, Daniel, Derecho internacional de los derechos humanos, Superior Tribunal Superior de Justicia del Distrito Federal, 2012.

Olea, Helena, "Los derechos humanos de las personas migrantes: respuestas del sistema interamericano", en El sistema interamericano de protección de los derechos humanos y los derechos de las poblaciones migrantes, las mujeres, los pueblos indigenas y los niños, niñas y adolescentes, Instituto Interamericano de Derechos Humanos, San José, 2004.

Rodríguez Pizarro, Gabriela, "Migrant workers. Report of the Special Rapporteur, Ms. Gabriela Rodríguez Pizarro, submitted pursuant to Commission on Human Rights resolution 2002/62", E/CN.4/2003/85, 30 de diciembre de 2002. 
Salvioli, Fabián, "La competencia consultiva de la Corte Interamericana de Derechos Humanos: marco legal y desarrollo jurisprudencial", en Homenaje y Reconocimiento a Antônio Cançado Trindade, Editorial Sergio Fabris, Brasilia, 2004, tomo III. 
